\title{
P81 - Clinical analysis of health education and self management combined with drug therapy in school-age children with asthma
}

\author{
Yuanqing Chen \\ From 3rd Pediatric Allergy and Asthma Meeting (PAAM) \\ Athens, Greece. 17-19 October 2013
}

\section{Objective}

To evaluate the effects of health education and self management intervention combined with drug therapy in school-age children with asthma.

\section{Methods}

320 cases of school-age children with asthma were divided into management group and control group, two groups of children were receiving standardized drug inhale treatment, management of children receive regular health education and self management behavior intervention.

\section{Results}

Times of asthma attacks, emergency and missing school days decreased significantly compared with the control group. Pulmonary function improved.

\section{Conclusion}

The health education and self management behavior intervention combined with drug therapy can improve the level of understanding of disease in children with asthma, medication compliance, reduce symptoms, improve lung function and improve the quality of life.

Published: 28 February 2014

doi:10.1186/2045-7022-4-S1-P136

Cite this article as: Chen: P81 - Clinical analysis of health education and self management combined with drug therapy in school-age children with asthma. Clinical and Translational Allergy 2014 4(Suppl 1):P136.

\footnotetext{
Child Health Care, Women and Children Health Institute, Futian, Shenzhen,
}

Submit your next manuscript to BioMed Central and take full advantage of:

- Convenient online submission

- Thorough peer review

- No space constraints or color figure charges

- Immediate publication on acceptance

- Inclusion in PubMed, CAS, Scopus and Google Scholar

- Research which is freely available for redistribution 